\title{
THE EVOLUTIONS OF CHINA'S GEOPOLITICAL INTERESTS AND POLICIES IN CENTRAL ASIA
}

\author{
ЕВОЛЮЦІЯ ГЕОПОЛІТИЧНИХ ІНТЕРЕСІВ І ПОЛІТИКИ КНР \\ У ЦЕНТРАЛЬНІЙ АЗІї
}

\author{
Cai Yao, \\ Postgraduate student \\ Institute of International Relations of Taras Shevchenko National University of Kyiv
}

Central Asia is between China, Russia, the Caucasus, and West Asia and refers to five landlocked countries, including Kazakhstan, Uzbekistan, Kyrgyzstan, Tajikistan, and Turkmenistan. The geographic location of Central Asia is significant. After the end of the Cold War, the geopolitical layout of Central Asia has undergone tremendous changes. The People's Republic of China (PRC) has quickly established normal diplomatic relations with countries in Central Asia and has actively participated in regional affairs as an "Extra-regional Actors" how to resolve the border issues left over by the Soviet Union with the Central Asian countries and Russia to maintain regional security has become China's primary demand in Central Asia in the 1990s. After the 9.11 incident, the United States launched the Global War on Terrorism and deployed military forces to Afghanistan and Central Asia. At the same time, Central Asia is facing increasingly non-traditional security threats, and its position in the world energy structure is also increasingly important. These have become the background of China's current Central Asia policies. The purpose of this article is to study geopolitical characteristics and historical changes in Central Asia and their impaction on China, and on this basis, analyze the formation process of China's current Central Asia strategy. Firstly, the author analyses the geopolitical impact of Central Asia on China and its historical changes. In different historical periods, the geopolitical influence of Central Asia on China is distinct. Combined with historical analysis, the article points out that geopolitical security and energy sources are the keys to understanding China's current policy in Central Asia. Secondly, the article analyzes the acknowledgment and function of Central Asia in the Belt and Road Strategy. As China's important foreign strategy, the one fundamental goal of the Belt and Road is to promote regional economic integration. Although the trade amount between Central Asia and China is still not much in total, the region is one of the essential points of China's geopolitical interests. The article states that the PRC has formed a stable Central Asia policy. China's policies emphasize regional integration and the regional security complex to meet non-traditional security challenges. Central Asia has gradually changed from energy and regional security partners of functional meaning to an essential part of China's geopolitical strategy. Beijing wants to protect its strategic interests in Central Asia by providing regional public products and promoting regional integration.

Key words: China, Central Asia, Geopolitical interests, Geopolitical strategy, Shanghai Cooperation Organization, The Belt and Road.

Центральна Азія знаходиться між Китаєм, Росією, Кавказом і Західною Азією і відноситься до п'яти країнам, які не мають виходу до моря, включаючи Казахстан, Узбекистан, Киргизстан, Таджикистан і Туркменістан. Географрічне положення Центральної Азії має важливе значення. Після закінчення холодної війни геополітичне становище Центральної Азії сильно змінилося. Китайська Народна Республіка (КНР) швидко встановила нормальні дипломатичні відносини з країнами Центральної Азії та активно бере участь в регіональних справах як «позарегіональних суб'єктів». Як розв'язувати прикордонні проблеми, залишені Радянським Союзом з країнами Центральної Азії та Росією для підтримки регіональної безпеки, стало основною вимогою Китаю в Центральній Азії в 1990-х роках. Після Терористичних актів 11 вересня Сполучені Штати почали Боротьбу з міжнародним тероризмом і розгорнули військові сили в Афрганістані та Середньої Азії. У той же час Центральна Азія стикається зі все більш нетрадиційними загрозами безпеці, і її положення у світовій енергетичній структурі також набуває все більшого значення. Ці чинники є фоном нинішньої політики Китаю щодо Центральної Азії. Мета статті - вивчити геополітичні характеристики та історичні зміни в Центральній Азії і їх вплив на Китай, на основі якого проаналізувати процес формування нинішньої стратегії Китаю в Центральній Азії. По перше, це дослідження вивчає геополітичний вплив Середньої Азії на Китай та його історичні зміни. У різні історичні періоди геополітичний вплив Середньої Азії на Китай різний. Використовуючи історичний метод в статті вказується, що геополітична безпека і джерела енергії є ключем до розуміння поточної політики Китаю в Центральній Азії. По-друге, в статті аналізуються ступінь визнання і роль Центральної Азії в стратегії «Один пояс, один шлях». Одна з основних цілей ініціативи «Один пояс, один шлях», бувши важливою зовнішньої стратегії Китаю - сприяти регіональній економічній інтеграції. Хоча загальний обсяг торгівлі між Центральною Азією та Китаєм і раніше невеликий, цей регіон є одним з найважливіших пунктів геополітичних інтересів Китаю. У статті зазначається, що КНР сформувала стабільну політику щодо Середньої Азії. Політика Китаю наголошує на регіональній інтеграції та регіональному комплексі безпеки для вирішення нетрадиційних викликів безпеці. Центральна Азія поступово перетворилася з партнерів у сфері енергетики та регіональної безпеки, що мають функціональне значення, у важливу частину у сфері геополітичної стратегії Китаю. Щоб захистити свої стратегічні інтереси в Центральній Азії, Пекін пропонує регіональні громадські продукти та просуває регіональну інтеграцію.

Ключові слова: Китай, Центральна Азія, геополітичні інтереси, геополітична стратегія, Шанхайська організація співпраці, Один пояс, один шлях. 
Introduction. In 1904, the famous British scholar Halford Mackinder put forward the Heartland Theory, listing Central Asia and Eastern Europe as the core regions that will play an important role in the world's political structure [1, p. 298, 321]. The American scholar Zbigniew Brzezinski referred to Central Asia, the Caucasus, and the Caspian Sea as the notion of Greater Central Asia [2, p. 16]. He believed that this region's vast energy reserves and necessary mineral resources would cause competition between major powers and become the Balkan of Eurasia.

Central Asia has a significant influence on the PRC's national security, international cooperation, energy supply, and regional development, and it occupies an important position in Beijing's geostrategy and foreign policy. With the growth of China's influence in Central Asia, especially after the "Belt and Road" Initiative (BRI) was put forward, China's geopolitical interests and geostrategy in Central Asia have become important issues in related academic research.

This article's main goal is to study geopolitical characteristics and historical changes in Central Asia and their impact on China, and on this basis, analyze the formation process of China's current Central Asia strategy.

Recent literature review. Ukrainian scholar Lyudmyla Chekalenko reviews the scheme of China's implementation of the concept of the economic Silk Road in Middle Asia, points out that China has adopted a "soft" project (М'який варіант) in Central Asian affairs after the Cold War. This strategy promotes China's influence on Central Asian countries' leaders and achieved great success in economic interests [3]. M. Murashkina and S. Tolstov analysis China's strategic interests in Central Asia and the main directions of Chinese foreign policy for their implementation [4]. Mingazutdinova G. I. analyses the Central Asian region's conceptual framework in the global historical and political tradition in the XIX-XX centuries [5]. Many researchers have also analyzed the policies and interactions of different forces surrounding Central Asia, such as US policy towards Central Asian region of the CIS: political retrospective of the postbipolar times, Central Asia as a zone of intersection of interests of competing states: prospects of rivalry and interaction, Today Russia is no longer able to compete with China and Turkey in the Central Asian region, etc. [6] For now, research on related issues has produced a lot of results. But many studies did not involve discussions on the formation process of China's Central Asia strategy. After the Cold War, Beijing's strategic perception of Central Asia has been continuously evolving.

The main part of the article.

1. The evolutions of Central Asia's geopolitical influences on China.
In history, Central Asia and Xinjiang were called the "Western Regions" (Xiyu, 西域), and China's central dynasty exerted influence in this area several times and established a critical trade channel-the Silk Road. Traditionally, the term "Western Regions" could refer to several connected geographical regions. In its broader sense, it denotes the entire area west of Yumen Pass in Dunhuang (Yumen Pass is the name of a pass of the Great Wall located west of Dunhuang in today's Gansu Province of China), which referred to Xinjiang and Central Asia; in its narrower sense, it includes only Southern and Eastern Xinjiang. Due to ancient technology limitations, the Central Plains dynasty's management of the Western Regions was essentially defensive, generally limited to The Pamir Mountains (Named "Congling Mountains" in history, 苾岭). Central Asia to the west of the Pamir Mountains has always been scattered and weak tribes in ancient times. The challenge of these tribes is nonthreatening to the Central Plains Dynasty. Influences of the Tang Dynasty were once as far as the east coast of the Caspian Sea, but since the Battle of Talas's failure (怛罗斯之战) in $751 \mathrm{AD}$, the area's expansion has been terminated [7]. The Mongols' conquest of Central Asia was part of Eurasia's conquest, and the Yuan Dynasty (1279-1368 AD) established by the Mongols soon dissipated in Chinese history. Generally speaking, since the Chinese political center moved eastward from Xi' an in the late Tang Dynasty, the northwestern region has long been a marginal area of ancient China's geopolitical structure. There has been no long-term stable force that can pose a fundamental threat to the empire in central China. Only when the north or northwest minority invaded and constituted a threat to the major empire would the northwestern region's strategic position become significant to the central empire or dynasty.

In 1881 year, the Russian Empire (1721-1917) conquered the tribes of Turkmenistan and completed the military occupation of the entire Central Asia. Since then, Central Asia merged into the territory of the Russian Empire. During the Russian Empire and the Soviet Union, Central Asia had a substantial geopolitical influence on China. After the First Opium War (or the Anglo-Chinese War, 1839-1841), the Qing Empire gradually declined. The Russian Empire passed unequal treaties and seized over 1.5 million square kilometers outside China in the northeast and northwest [8]. After 1910, the October Revolution broke out in the Russian Empire. The October Revolution didn't fundamentally change the previous expansion policy. During the Republic of China, with the support of the Soviet Union, Outer Mongolia became independent, and Tannu Uriankhai (Таңды Урянхай) was annexed by the Soviet Union [9]. The Soviet Union continues to use Central Asia as its foundation to expand influence in neighboring countries. During this period, some Soviet Union 
leaders put forward a proposal to support China's Xinjiang's “independence”. In the late 1930s, the threat of the fascist governments in Germany and Japan was becoming increasingly severe, and the Soviet government actively developed friendly relations with neighboring countries around Central Asia to ensure the strategic rear's safety. Therefore, the Soviet Union's support for the separatist forces in Xinjiang gradually weakened during this period.

In 1949, due to the rapid military victory of the Chinese Communist Party, the Soviet Union stopped intervention in Xinjiang. After the PRC's founding, the border between Central Asia and the PRC remained calm for more than a decade. In the 1960s and 1970s, the relationship between the two countries became deteriorating. The latter once again intervened in Xinjiang affairs. At that time, the Soviet Union's strategic intent was to encircle the PRC from the east and west wings. The Soviet Union significantly increased its military power in Central Asia, making Central Asia a base to implement northern China's strategic encirclement. In November 1979, the Soviet army aggressively invaded Afghanistan. During this period, Central Asia's status within the Soviet Union improved because it became a geopolitical fulcrum for confrontation. The Soviet Union's military deployment in Central Asia increased unprecedented intensity, and China has also endured huge geosecurity threats.

Since the independence of Central Asian countries, the geopolitical status in Central Asia has undergone tremendous changes, and this region is still confronted with many security challenges. There have been two peak periods when regional security has been seriously threatened: one is the civil war in Tajikistan (1992-1997); the other is when the Uzbek Islamic Movement attacked southern Central Asia as a representative of the active extremist period (19992000). However, the entire region did not have largescale chaos caused by war but maintained primary stability. To resolve the border issues left over by the Soviet Union with the Central Asian countries and Russia to maintain regional security has become China's primary demand in Central Asia in the 1990s.

After the 9.11 incident, the United States launched the Global War on Terrorism and deployed military forces to Afghanistan and Central Asia. At the same time, CentralAsia is facing increasingly non-traditional security threats, and its position in the world energy structure is also increasingly important. New changes have taken place in the geopolitical characteristics of Central Asia. Compared with the 1990s, Central Asia's security situation has shown some new features in the 21st century. Central Asian countries are currently not facing external military invasion in terms of traditional security, nor will there be a chain reaction similar to many countries in West Asia and North Africa. The overall security situation is controllable. Problems that may destabilize the country within the region include: first, political turmoil and escalation of political struggles - Crises or agitation caused by different interest groups, regional groups, and tribal (the family of power) forces fighting for power; second, social conflicts (including ethnic and religious conflicts) - Dissatisfaction among some social groups erupts, extremism is widespread, and violence against the regime or other social groups escalates. The third is border disputes-security issues related to border demarcation, and border control may lead to the deterioration of relations between Central Asian countries. The current problems mainly exist in the Fergana Region between Uzbekistan, Kyrgyzstan, and Tajikistan. After the Islamic State of Iraq and Syria (ISIS) was defeated in the Middle East, it intends to expand Afghanistan's influence. The issue of extremist thoughts and the "return" of Jihadists posed a challenge to Central Asian countries. These challenges also have an impact on countries or regions surrounding and outside the area [10]. These have become the background of China's current Central Asia policies.

2. Geopolitical security and energy sources are the keys to understanding China's current policy in the Central Asian.

Geopolitical Security. In the early and mid1990s, China mainly sought to resolve border issues with Central Asia countries and Russia. This problem was a historical legacy of Sino-Soviet relations. In the context of the improvement of Sino-Soviet relations, the two countries held border negotiations in 1989. After the Soviet Union's disintegration, the SinoSoviet border negotiations naturally became a bilateral negotiation with China on one side and Russia, Kazakhstan, Kyrgyzstan, and Tajikistan. At that time, about 19 border areas caused disputes between China and the other four countries, and the disputed border area was approximately $34,000 \mathrm{~km}^{2}$. After ten years of border negotiations, the results between China and Kazakhstan, Kyrgyzstan, and Tajikistan are as follows (see table 1). The disputed areas between China and Russia are more complicated. In 2004, China and Russia signed the "Supplementary Agreement between the People's Republic of China and the Russian Federation on the Eastern Section of the Sino-Russian Border" [11]. After more than 30 years and three rounds of diplomatic negotiations, China and Russia finally completed border negotiations [12].

Closely related to border disputes are traditional security issues. On April 26, 1996, to resolve border issues left over from history and strengthen military trust in border areas after the disintegration of the Soviet Union, the leaders of China, Russia, Kazakhstan, Kyrgyzstan, and Tajikistan met in Shanghai and signed the "Agreement between Russia, Kazakhstan, Kyrgyzstan, Tajikistan, and China 
on Confidence Building in the Military Field in the Border Area" [13]. According to the Agreement: The two sides' military forces in the border area will not attack each other; The two sides will not hold military exercises against each other; Limit the scale, geographic scope, and frequency of military exercises; Inform each other of critical military activities on each side of the border; Invite observers to observe military training; Strengthen military exchanges in the border areas of the two sides, etc. The Agreement promoted peace, stability, and tranquillity between China and the northwestern border region and officially launched the Shanghai Five mechanism.

In April 1997, the Five Countries mentioned above signed "The agreement between the Russian Federation, the Republic of Kazakhstan, the Kyrgyz Republic, the Republic of Tajikistan and People's Republic of China on mutual reducing armed forces around border" in Moscow [14]. The main content of the Agreement is: the two sides reduce the military power in the border area to the lowest level compatible with good-neighborly and friendly relations, making it only defensive; confirming mutual nonuse of force or threats of force, refusal of aspiration to receive unilateral military superiority; limit the number of staff and quantity of main types of arms and military equipment of land forces, the Air Force and aircraft of air defense deployed in geographical limits of application of the Agreement and will establish for their limits.

Therefore, as the SCO's predecessor, the original purpose of the Shanghai Five-nation Mechanism was to solve traditional security issues, including border demarcation, military forces in border areas, regional nuclear weapons control, and security assurance, etc. [15]. Since then, in the cooperation process, the Five Countries have gradually formed a consensus that the dialogue between the five countries is not limited to military politics and border issues and progressively focuses on regional security issues, especially nontraditional security. These issues include fighting against religious extremist forces that endanger the region, ethnic separatist forces, and international terrorist forces [16].

On July 5, 2000, President Karimov (Карімов Іслам Абдуганійович) of Uzbekistan participated in the "Shanghai Five" Summit in Dushanbe for the first time as an observer country. The increase in areas of cooperation and the deepening of the level of collaboration, the participation interests and desires of neighboring countries, and the increasing complexity of the international situation and the situation in Central Asia have all prompted the "Shanghai Five" mechanism to be upgraded to a regional cooperation organization. In June 2001, the "Shanghai Five" mechanism was upgraded to the SCO, marking a new regional cooperation stage among China, Russia, and Central Asian countries.
On 13-14 June 2019, Bishkek hosted an SCO's Heads of State Council meeting. The "Bishkek Declaration of the SCO's Heads of State Council" emphasized that the Member States believe in increasing challenges and security threats that are becoming Cross-border Issues [17]. Since its founding in 2001, the SCO has developed from a loose and temporary alliance that mainly focuses on border issues to a stable international organization covering regional security, economic cooperation, energy, and transportation construction. After the Cold War, the emergence of non-traditional security problems makes the region the main platform of security cooperation among different nations [18]. The Shanghai Cooperation Organization (SCO) is the foundation of China's regional policy towards Central Asia; its establishment reflects the expansion of China's attention to geo-security in Central Asia, from traditional security to non-traditional security. The SCO is becoming a new regional security community.

Energy Sources. Since the 21st century, with the rapid development of China's economy, the energy demand has increased, and more and more problems have been exposed in the energy field. In 2010, China's total energy consumption surpassed the United States for the first time, becoming the world's largest energy-consuming country. In the first 20 years of the 21 st century, China has made outstanding energy development achievements, its supply capacity is significantly improving, and its structure is also be optimized. China has formed energy channels in four directions: The northwest is the ChinaKazakhstan crude oil pipeline and the Central Asia natural gas pipeline; The northeast is the crude oil pipeline between China and Russia; The southwest is the crude oil pipeline and natural gas pipeline between China and Myanmar; The Offshore oil and gas import routes - most of China's oil imports rely on transportation through Malacca's Straits.

Central Asia is rich in oil and gas resources and is the only overseas onshore oil and gas source close to China, with short transportation distances. This energy corridor doesn't need to pass through a third country and is not affected by coastal states and regions along the way. Compared with sea transportation, land channel transportation are large volumes, safe and stable, reducing the pressure on sea energy imports [19]. As China's dependence on imported oil and gas increases, Central Asia's position in China's energy strategic layout has improved. Central Asia is incredibly rich in natural gas resources. Turkmenistan is the world's fourth-largest natural gas reserve country and a major natural gas producer and exporter. From Central Asian countries' perspective, in recent years, they had relatively rapid economic growth. Expanding the development and export of oil and natural gas resources has become essential for national economic 
development. After independence, Central Asian countries actively diversify their oil and gas exports to eliminate Russian control and maximize their national interests. China provides necessary capital, technology, and consumer markets for the oil and gas development of Central Asian countries and promotes the diversification of oil and gas exports in Central Asian states. The Central Asia - China gas pipeline starts from Turkmenistan and Uzbekistan's borders in the west, passes through central Uzbekistan and southern Kazakhstan, and enters through the Dry Port Khorgos in Xinjiang, China. Currently, the ABC three lines are paralleled. The natural gas transported from Central Asia to China accounts for more than $15 \%$ of total consumption each year [20].

\section{Supplement and integration of China's policy} in Central Asia - The Belt and Road Strategy and Central Asia.

The bilateral trade between China and Central Asian countries has always been mainly trading in goods. At the beginning of establishing diplomatic relations between China and Central Asian countries, the two sides' economic and trade ties did not develop rapidly. On the one hand, for China, after the disintegration of the Soviet Union, the five Central Asian countries all fell into economic difficulties to varying degrees, and their economic ties with the outside world were limited. On the other hand, during this period, China's economic policy was still concentrated in the eastern coastal areas, so it did not pay much attention to regional economic cooperation in Central Asia.

But for now, the economic importance of china's role and impact in Central Asia is apparent. In each of the five Central Asian republics, China has become a significant financial partner through natural resource extraction projects, infrastructure investments, and low-interest loans. In the first decade of the 21st century, China has strengthened energy cooperation with Central Asia and increased investment (see table) in the region due to energy demand and bilateral economic development [21]. In 2017, China was the second-largest trading partner of Kazakhstan and Tajikistan and the largest trading partner of Uzbekistan, Turkmenistan, and Kyrgyzstan. Compared with the establishment of diplomatic relations between China and Central Asian countries in 1992, the bilateral trade volume between China and Kazakhstan, Uzbekistan, Turkmenistan, Kyrgyzstan, and Tajikistan increased by more than 40 times, 90 times, 1500 times, 150 times, and 450 times respectively [22].

The SCO was co-created by China, Central Asian countries, and Russia. Its establishment has made China's influence on Central Asia more institutionalized. Relying on the organization, China focuses on counter-terrorism cooperation with other security fields. Although China tried to expand the SCO functions, it has always differed from the Russian-led regional mechanisms in function and focuses. China and Central Asian members want to improve multilateral economic cooperation within the SCO framework in the economic domain. Still, due to the Russian factor's existence, the SCO's economic cooperation has always lagged behind security cooperation for a long time [23]. Therefore, China began to seek mechanisms to promote economic cooperation with Central Asia outside the SCO framework. The purpose is to avoid a more proactive regional policy from negatively affecting the SCO's cooperation in non-traditional security fields. It's also an important reason why China agreed to expand the membership of the SCO.

On October 24, 2014, the 21 first batch of founding member countries, including China, India, Singapore, etc., formally signed the Memorandum ofUnderstanding on Establishing the Asian Infrastructure Investment Bank (AIIB) in Beijing, jointly deciding to establish the AIIB [24]. In November, China announced investing $\$ 40$ billion to establish the Silk Road Fund to support the Belt and Road construction. In March 2015, China issued the Vision and Actions on Jointly Building Silk Road Economic Belt and 21st Century Maritime Silk Road, which clarified the roadmap for constructing the Belt and Road [25].

Central Asian countries such as Kazakhstan and Uzbekistan are more active than Russia in

Comparison of direct investment flows of China (US \$10000)

\begin{tabular}{|c|c|c|c|c|c|c|c|c|c|c|c|}
\hline State & 2003 & 2005 & 2007 & $\mathbf{2 0 1 0}$ & $\mathbf{2 0 1 1}$ & $\mathbf{2 0 1 2}$ & $\mathbf{2 0 1 3}$ & $\mathbf{2 0 1 4}$ & $\mathbf{2 0 1 5}$ & $\mathbf{2 0 1 6}$ & $\mathbf{2 0 1 7}$ \\
\hline Kazakhstan & 294 & 9493 & 27992 & 3606 & 58160 & 299599 & 81149 & -4007 & -251027 & 48770 & 207047 \\
\hline Kyrgyzstan & 244 & 1374 & 1499 & 8247 & 14507 & 16140 & 20339 & 10783 & 15155 & 15874 & 12370 \\
\hline Tajikistan & 0 & 77 & 6793 & 1542 & 2210 & 23411 & 7233 & 10720 & 21931 & 27241 & 9501 \\
\hline Uzbekistan & 72 & 9 & 1315 & -463 & 8825 & -2679 & 4417 & 18059 & 12789 & 17887 & -7575 \\
\hline Turkmenistan & 0 & 0 & 126 & 45051 & -38304 & 1324 & -3243 & 19515 & -31457 & -2376 & 4672 \\
\hline
\end{tabular}

Source: authors' calculations based on [Statistical Bulletin of China's Outward Foreign Direct Investment (2003-2017)] 
dealing with China's the Belt and Road initiative. The two countries are the first batch of intentional founding members of the AIIB to formally sign the memorandum in October 2014. Russia did not announce its participation in the AIIB initiated by China until March 29, 2015, when the application deadline approached. The third meeting of negotiators to prepare for establishing the AIIB (on March $30,2015)$ was also held in Almaty, which shows Kazakhstan's active support for the AIIB [26]. Reasons for this change: on the one hand, China's rapid economic growth has attracted Central Asian countries to cooperate with China; on the other hand, the Russo-Georgian War (2008) and the annexation of Crimea (2014) make the CIS afraid of the Kremlin cannot keep its security commitments, and more cautious about Russia-led regional mechanisms [27].

The Belt and Road marked a new stage of China's geopolitical policy in Central Asia, and it has received positive responses from some regional countries. Although the trade amount between Central Asia and China is still not much in total, the region is one of the essential points of China's geopolitical interests. As China's important foreign strategy, the one fundamental goal of the Belt and Road is to promote regional economic integration; it also determines the characteristics of the new stage of China's Central Asia policy. China's policy towards Central Asia emphasizes regional integration and constructing a regional security complex (RSC) and brings Central Asia into China's foreign policy of regional governance. Compared with Russia, China can provide more funds, markets, and technology for economic development in Central Asia. Providing regional public goods and promoting regional integration is the new direction for China's foreign policy in Central Asia affairs. China tries to shape itself as a participant rather than a revisionist in the regional order.

Conclusions. Strategic security is China's most fundamental interest in Central Asia. China's security interests in Central Asia are not only an essential part of China's peripheral security interests but also a necessary part of the overall interests of China's national security strategy. At present, China's security interests in Central Asia have mainly included three aspects: Combating the terrorist forces and related organizations; Maintaining the security, stability, and development of China's northwestern frontier; Establishing a new channel for energy transportation in Central Asia-China and eliminating Chinese energy Security risks [28].

With China's domestic development and changes in Central Asia's geopolitical situation, Central Asia has gradually changed from an energy partner to an essential part of China's geopolitical strategy, and economic ties between China and Central Asia are also getting closer. Therefore, China will be more actively involved in the regional affairs of Central Asia. Simultaneously, China's understanding and policies on Central Asia's geopolitical interests have become increasingly mature.

China insists on non-interference and cooperation in Central Asia affairs, but still with many conflicts between Russia, the United States, and other forces. To participate in regional affairs and achieve regional integration goals to Promote domestic economic development, China tries to expand the original regional boundary and construct a more comprehensive model for supplying regional public goods. Beijing respects Russia's traditional influence in Central Asia and avoids conflicts with the United States' presence in Central Asia. Regardless, the complicated security situation and the regional imbalances in economic conditions will bring challenges and risks to China's Central Asia policies. China's policies and influence in Central Asia require long-term observation and research.

\section{REFERENCES:}

1. Mackinder H. J. The geographical pivot of history. The Geographical Journal. 2004. № 4. C. 298-321.

2. Zbigniew Brzezinsk. The Grand Chessboard: American Primacy and Its Geostrategic Imperatives. Shanghai : Shanghai Renmin Press, 1998. 16 c.

3. Чекаленко Л. КНР - Середня Азія: реалізація концепції економічного шовкового шляху. Україна-Європа - Світ. Міжнародний збірник наукових праць. 2017. № 20. С.148-156.

4. Мурашкина М.3. Основные направления политики Китая в регионе Центральная Азия. Вісник Маріупольського державного університету. Сер. : Історія. Політологія. 2013. № 7-8. С.175-184.

5. Мінгазутдінова Г.І. Формування поняття Центральної Азії як стратегічного регіону в XIX-XX ст. та її історико-географрічні характеристики. Гілея. 2016. № 10. С. 24-29.

6. Дудко І.Д. Політика США щодо Середньоазійського регіону СНД: політична ретроспектива постбіполярних часів. Політикус. 2020. № 3. С. 122-130; Кривоглава М.3. Центральна Азія як зона перетину інтересів конкуруючих держав: перспективи суперництва та взаємодії. Держава і право. 2011. № 54. С. 739-743; Вадим Волохов. На сьогодні Росія вже не спроможна конкурувати з Китаєм і Туреччиною в регіоні Центральної Азії. Незалежний аналітичний центр геополітичних досліджень «БОРИСФЕН IHTEЛ». URL: https://bintel.org.ua/ analytics/geopolitics/centralna-aziya-yabluko-rozbratu/ (дата звернення: 10.06.2021).

7. The core of the policy of Tang Dynasty in the Western regions is to insure the safety of the area to the east of Congling and prevent the joint invasion of Tibetan Empire and West Turkistan. The rule of Tang Dynasty in 
central Asia and to deal with the challenge from Dashi become secondary. Refer to: Li Fang. Daluosi Battle and the Policy of Tang Dynasty. China's Borderland History and Geography Studies. 2006. № 01. C. 56-65; W. Travis Selmier. The Belt and Road Initiative and the influence of Islamic economies. Economic and Political Studies. 2018. № 06. C. $257-277$.

8. Li Na. A Summary of Historical Facts of the Russian Empire's Invasion in China's Xinjiang. Journal of Changji University. 2003. № 03. C. 57-60.

9. Wu Fuhuan, Miao Jian. China's Frontier Crisis before the Revolution of 1911. Journal of Xinjiang University (Social Science Edition). 2001. № 04. C.35-42.; Fan Mingfang. The history of Tannu Uriankhai was merged into the Soviet Union. China's Borderland History and Geography Studies. 1997. № 02. C.59- 65.

10. Цай Яо. Чому Китай бере участь у регіональному управлінні Центральною Азією - 3 точки зору регіональних громадських благ. Гілея. 2018. № 01. С. 355-360.

11. Peace Agreements Database. Supplementary Agreement between the People 's Republic of China and the Russian Federation on the Eastern Section of the Sino-Russian Border. URL: https://www.peaceagreements.org/ view/1743.

12. Lu Guicheng. Experiencing Sino-Soviet Border Negotiations. Russian Studies. 2019. № 04. C.16-24.

13. Agreement between Russia, Kazakhstan, Kyrgyzstan, Tajikistan and China on Confidence Building in the Military Field in the Border Area. URL: https://peacemaker.un.org/regional-confidencebuildingborders96. (дата звернення: 02.05.2021).

14. The agreement between the Russian Federation, the Republic of Kazakhstan, the Kyrgyz Republic, the Republic of Tajikistan and People's Republic of China on mutual reducing armed forces around border. URL: https://cis-legislation.com/document.fwx?rgn=3872. (дата звернення: 15.05.2021).

15. Xing Gangcheng. Security Cooperation between China and Central Asian Countries. World Economics and Politics. 1998. № 09. C.40-45.

16. Lin Minjing, Liu Jiangyong. The Formation of the Shanghai Cooperation Organization and Its Motivation. Quarterly Journal of International Politics. 2009. № 01. C. 1-33.

17. The SCO (2019) Bishkek Declaration of the Shanghai Cooperation Organisation's Heads of State Council. URL: http://eng.sectsco.org/documents/. (дата звернення: 25.05.2021).

18. Yu Jianhua, Dai Yichen. On Regional Governance of Non-traditional Security and Shanghai Cooperation Organization. Journal of Social Sciences. 2009. № 07. C. 19-28.

19. Shi Mingyu, Qi Mei, Yi Chenggao, CHEN Rong, Bai Jianhui. Strategic prospect of oil/gas pipeline in the region of Central Asia- Caspian Sea and its influence on China's energy security. Oil \& Gas Storage and Transportation. 2018. № 12. C. 1321-1328.

20. National Energy Administration (2019). The Central Asia-China gas pipeline delivered more than 23 billion cubic meters of gas to China in the first half of the year. URL: http://www.nea.gov.cn/2019-08/02/c_138278567.htm. (дата звернення: 26.05.2021).

21. Data from MINISTRY OF COMMERCE PEOPLE'S REPUBLIC OF PRC. Statistical Bulletin of China's Outward Foreign Direct Investment. URL: http://fec.mofcom.gov.cn/article/tjsj/. (дата звернення: 27.05.2021).

22. Data from National Bureau of Statistics of PRC. URL: http://www.stats.gov.cn/english/. (дата звернення: 27.05.2021).

23. Li Jinfeng. Enlargement of the Shanghai Cooperation Organization : Challenges and Opportunities. Russian Central AsianEast European Studies. 2015. № 06. C.36-44.

24. AlIB. The Memorandum of Understanding on Establishing the Asian Infrastructure Investment Bank (AllB) was signed in Beijing. URL: https://www.aiib.org/en/news-events/news/2015/The-Memorandum-of-Understanding-onEstablishing-the-Asian-Infrastructure-Investment-Bank-was-signed-in-Beijing.html. (дата звернення: 28.05.2021).

25. Belt and Road Forum for International Cooperation (2017) . Full Text-Vision and actions on jointly building Belt and Road. URL: http://2017.beltandroadforum.org/english/n100/2017/0410/c22-45.html. (дата звернення: 28.05.2021).

26. ASIAN INFRASTURUCTURE INVESTMENT BANK (2015). The 3rd Chief Negotiators' Meeting took place in Almaty. URL: https://www.aiib.org/en/news-events/news/2015/The-3rd-Chief-Negotiators-Meeting-took- place-inAlmaty-Kazakhstan-on-March-30-31-2015.html. (дата звернення: 29.05.2021).

27. Farkhod Tolipov. Strategic Implications of the War in Ukraine for the Post-Soviet Space: A View from Central Asia. Connections. 2015. №4. C.11- 20.

28. Reference to: Li Tongsheng, Long Dongping. Geopolitical position of Central Asian countries and geopolitical strategy of China. Progress in Geography. 2014. № 03. C.303-314; Luo Yingjie. Security Situations in Central Asia: Changes and Impacts. Journal of International Security Studies. 2014. № 02. C.103-124; Pan Zhiping. Xinjiang's Geopolitics and Our National Security - A Historical and Status Quo Examination. China's Borderland History and Geography Studies. 2003. № 03. C. 57-67. 